Original article

\title{
Impact of tree species on soil solutions in acidic conditions
}

\author{
Laurent Augusto and Jacques Ranger* \\ Institut National de la Recherche Agronomique, Centre de Recherches Forestières de Nancy, \\ Équipe Cycles Biogéochimiques, 54280 Champenoux, France
}

(Received 1st September 1999; accepted 5 June 2000)

\begin{abstract}
Capillary solutions of two acidic forest topsoils were sampled for one year. On each of the two soils, there were three stands (Norway spruce, Douglas fir, Hardwood). Capillary solutions were extracted using the centrifugation method. Soil moisture under Hardwood stands was higher than under coniferous stands. Soil solutions under the coniferous tree species were more acidic and more concentrated in $\mathrm{SO}_{4}^{-2}-\mathrm{S}$ and $\mathrm{Na}^{+}$than under Hardwoods, showing that coniferous tree species intercept atmospheric depositions more efficiently than hardwood tree species do. Soil solutions under hardwood stands were more concentrated in $\mathrm{K}^{+}$, Alt, Si and $\mathrm{Fe}^{3+}$ than those under coniferous stands. On the least desaturated site, soil solutions under the hardwood stand were less concentrated in $\mathrm{NO}_{3}^{-}-\mathrm{N}$ and $\mathrm{C}$ than under the coniferous stands. The amount of rainfall significantly influenced results by diluting soil solutions. When the amount of rainfall was high, there were little difference between tree species.
\end{abstract}

forest soil / tree species / soil solution / centrifugation / acidity

Résumé - Impact des essences forestières sur la composition des solutions du sol en conditions acides. Les solutions capillaires des horizons superficiels de deux sols forestiers acides ont été échantillonnées pendant une année. Sur chaque sol, trois peuplements étaient présents (Epicéa commun, Sapin Douglas, Feuillu). Les solutions capillaires ont été extraites des sols par centrifugation. L'humidité des sols sous feuillu est supérieure à celle sous résineux. Les solutions de sol sous résineux sont plus acides et plus concentrées en $\mathrm{S}_{-} \mathrm{SO}_{4}^{-2}$ et en $\mathrm{Na}^{+}$, ce qui témoigne d'une plus grande capacité de ces essences à capter les dépôts atmosphériques. Les solutions sous feuillus sont plus concentrées en $\mathrm{K}^{+}$, Alt, $\mathrm{Si}$ et $\mathrm{Fe}^{3+}$ que celles sous les résineux. Sur le site le moins désaturé, les

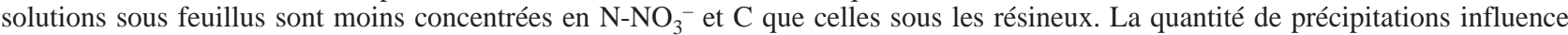
notablement les résultats en diluant les solutions de sol. Lorsque la pluviosité est très importante, les différences entre essences sont peu marquées.

sol forestier / essence forestière / solution du sol / centrifugation / acidité

\section{INTRODUCTION}

For more than a century, tree species substitution has been quite a common phenomenom in western Europe. The choice of the tree species planted plays an important role in the functioning of soils [7], particularly the topsoil. In France, two thirds of forests are composed of hardwood stands [34]. After the second world war, large areas were planted with coniferous tree species [34]: initially mainly with Norway spruce (Picea abies Karsten.), then with Douglas fir (Pseudotsuga menziesii (Mirb.) Franco). It is within this context that the present work studied the impact of Norway spruce, Douglas fir, European beech and Sessile oak on soil solutions.

* Correspondence and reprints

Tel. (33) 03833940 68; Fax. (33) 03833940 69; e-mail: ranger@nancy.inra.fr 
Soil solutions are important in the functioning of biogeochemical cycles of forest ecosystems as they are the main interface between vegetation, microflora, minerals and organic matters of soil [32]. The composition of soil solutions is the result of processes of production (weathering and mineralisation), deposition (atmospheric deposition; anthropic fertilization and liming) and consumption (by plants and by microorganisms). It is because of their central role that the study of soil solutions gives information on the nutrients available for the vegetation [10] or on the current level of soil acidification [30]. Except for hygroscopic solutions, Titus and Mahendrappa [49] distinguish two types of soil solutions: gravitational solutions and capillary solutions. The first transport existing products down to lower soil depths, whereas the second indicate the balance between the solid, the liquid and the living phases of soil [37]. There are many methods of extracting solutions from soils (see [49] for a review), which have an influence on solution composition. For instance, solutions from zero tension lysimeters are usually less concentrated (except for $\mathrm{Al}, \mathrm{Si}$ and $\mathrm{C}$ ) and their $\mathrm{pH}$ is lower than solutions extracted by centrifugation $[25,51]$. The centrifugation method has the following advantages: it does not necessitate any permanent in situ devices and it extracts capillary solutions, facilitating the study the internal functioning of soils [25].

The objective of this work was to determine the effects of tree species on the characteristics of soil capillary solutions. For this purpose, capillary solutions have been studied for one year using the centrifugation method for one year.

\section{MATERIALS AND METHODS}

A survey of soil solutions was performed in two acidic forest sites (table I): Haye and Remiremont. Both are arboretums established on a forest soil. In each forest, two coniferous stands and one hardwood stand were selected:

- Haye: Norway spruce (Picea abies (L.) Karst.), Douglas fir (Pseudotsuga Menziesii (Mirb.) Franco), Sessile oak (Quercus petraea (Mattus.) Liebl.).

- Remiremont: Norway spruce (Picea abies (L.) Karst.), Douglas fir (Pseudotsuga Menziesii (Mirb.) Franco), European beech (Fagus sylvatica L.).

The hardwood stand represented the forest state before the establishment of the arboretum. The main characteristics of the soils are presented in table II. Each stand has a plot size of at least $1000 \mathrm{~m}^{2}$.
Soils were described from a pedological pit. A bulk sample of five soil samples was analysed for each horizon. Horizons were analysed down to $40 \mathrm{~cm}$ in depth. The variables were: apparent soil density (cylinder method); particle size distribution (Robinson method); C content [2]; $\mathrm{N}$ content [12]; $\mathrm{pH}$ (soil:water ratio = 1.25); cationic saturation and cationic exchange capacity [42]; "available" phosphorus [19]; free iron and aluminium [47]. Daily meteorologic data (rainfall, minimum temperature and maximum temperature) were provided by meteorologic stations (Météo-France) near the sites.

Ten samplings were performed during the soil solutions study which was one year long (from April 1998 to April 1999). At each date, nine soil samples were taken in each stand. The nine points were distributed across the entire stand area so as to take into account the high spatial variability of forest soil chemical characteristics [13]. Each point was located under a tree canopy so as to take into account the impact of throughfall [8]. The distance from the point to the nearest trunk was between 1.0 to 1.5 meter because this parameter modifies the impact of throughfall [15] and stemflow [21, 29, 40]. Litter was removed and a stainless steel tube $(\mathrm{L}=15 \mathrm{~cm}$; $\varnothing=8 \mathrm{~cm}$ ) was vertically driven in. The soil was immediately put in a plastic bag. The hole was filled and its location was marked to avoid its being sampled at a later date. The locations of the samplings were always selected by the same operator. The nine samples were randomly grouped into three bulk samples. At each date, the sampling was performed in a single day and the samples were put in a shaded room at $4{ }^{\circ} \mathrm{C}$. Samples were analysed during the four days following the sampling.

Samples were sieved to $4 \mathrm{~mm}$. Soil water content (in $\%$ of dry weight) was measured (drying at $105{ }^{\circ} \mathrm{C}$ for 48 hours). Soil solutions were extracted by centrifugation of the samples in cylinders with an internal wall [25]: the internal wall is only permeable to water, preventing the soil sample from reaching the bottom of the cylinder (where the soil solutions collected) during centrifugation. The duration of centrifugation and speed were calculated so as to extract soil solutions up to around $\mathrm{pF}=4.2$. Preliminary tests have shown that, in such soils, the compositions of solutions extracted up to $\mathrm{pF}=3.3$ are identical $(p \leq 0.001)$ with those of solutions extracted between $\mathrm{pF}=3.3$ and $\mathrm{pF}=4.2$ (data not presented).

Solutions were filtered $(0.45 \mu \mathrm{m})$ and homogenized for analysis. $\mathrm{pH}$ was measured. $\mathrm{Al}_{\mathrm{t}}\left(\mathrm{Al}_{\mathrm{t}}=\right.$ total $\left.\mathrm{Al}\right), \mathrm{Fe}^{3+}$, $\mathrm{Mn}^{2+}, \mathrm{Si}, \mathrm{S}, \mathrm{Na}^{+}, \mathrm{K}^{+}, \mathrm{Mg}^{2+}, \mathrm{Ca}^{2+}$ and $\mathrm{PO}_{4}{ }^{2-}-\mathrm{P}$ were measured by atomic emission plasma troch spectrophotometry (ICP JY180 Ultrace, Jovin-Yvon). $\mathrm{NH}_{4}{ }^{+}-\mathrm{N}, \mathrm{NO}_{3}{ }^{-} \mathrm{N}$, $\mathrm{SO}_{4}{ }^{-2}-\mathrm{S}$ and $\mathrm{Cl}^{-}$were determined by colorimetry 


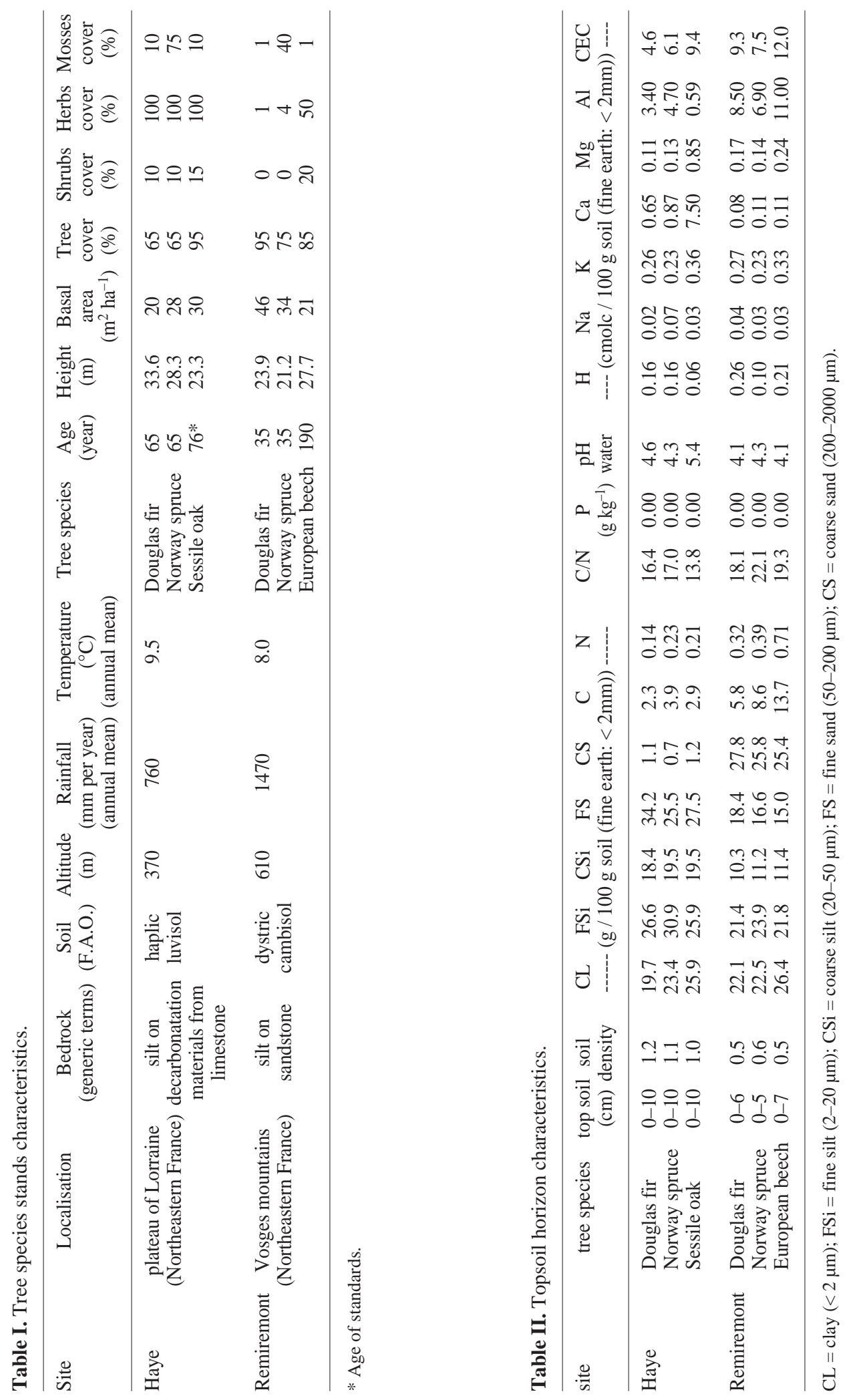


(TRAACS-2000, Bran-Luebbe). Ionic balance of solutions was defined as follows:

$$
\text { ionic balance }=\frac{\left(\sum \text { positive charges }-\sum \text { negative charges }\right)}{\left(\sum \text { positive charges }+\sum \text { negative charges }\right)} .
$$

As soils were acidic, Al was considered to be trivalent. Total organic carbon of solutions (DOC, noted here C) was measured (TOC-5050, Shimadzu). Comparative tests between $\mathrm{SO}_{4}{ }^{-2}-\mathrm{S}$ measured by colorimetry and $\mathrm{S}$ measured by spectrophotometry showed that all $\mathrm{S}$ in solutions was $\mathrm{SO}_{4}{ }^{-2}-\mathrm{S}$. Therefore, $\mathrm{S}$ was measured solely by spectrophotometry and considered to be $\mathrm{SO}_{4}{ }^{-2}-\mathrm{S}$.

The dataset was stastistically treated with SAS [43]. Variance analysis were performed in "repeated measurements" so as to take into account that data of a temporal series were not independent.

\section{RESULTS}

Meteorological data of the studied year (from April 1998 to April 1999) showed that it was slightly warmer and wetter year than the mean year (mean of 30 years).

\subsection{Differences between sites}

Rainfall was much lower at Haye $(813 \mathrm{~mm})$ than at Remiremont (1748 mm). Daily temperature differences (minimum temperature and maximum temperature) between sites were very small. The annual mean differences were less than $1{ }^{\circ} \mathrm{C}$. The annual mean temperature was $10.5^{\circ} \mathrm{C}$ at Haye and $10.0{ }^{\circ} \mathrm{C}$ at Remiremont. The solution $\mathrm{pH}$ was positively correlated $(p<0.001)$ to the amount of rainfall over the eight days before sampling (figure 1). This relationship between $\mathrm{pH}$ and rainfall was more clearly expressed at Remiremont $(p<0.001)$ than at Haye $(p<0.05)$. The most concentrated solutions were collected in autumn.

At Haye, $\mathrm{Ca}^{2+}$ and $\mathrm{Al}_{\mathrm{t}}$ were the dominant cations, whereas $\mathrm{Cl}^{-}, \mathrm{SO}_{4}{ }^{-2}-\mathrm{S}$ and $\mathrm{NO}_{3}{ }^{-} \mathrm{N}$ were the dominant anions. At Remiremont, $\mathrm{H}^{+}, \mathrm{Al}_{\mathrm{t}}$ and $\mathrm{Na}^{+}$were the dominant cations, whereas $\mathrm{Cl}^{-}$and $\mathrm{SO}_{4}{ }^{-2}-\mathrm{S}$ were the dominant anions (figure 2, table IIIa).

Soil water content at Haye $(33.6 \pm 1.1 \mathrm{~g}$ of water for $100 \mathrm{~g}$ of dry soil; $n=90)$ was significantly lower $(p<0.001)$ than at Remiremont $(56.3 \pm 2.1 ; n=90)$. There was almost no extractable water at Haye at three dates (from June to September 1998) and at Remiremont at one date (July 1998).

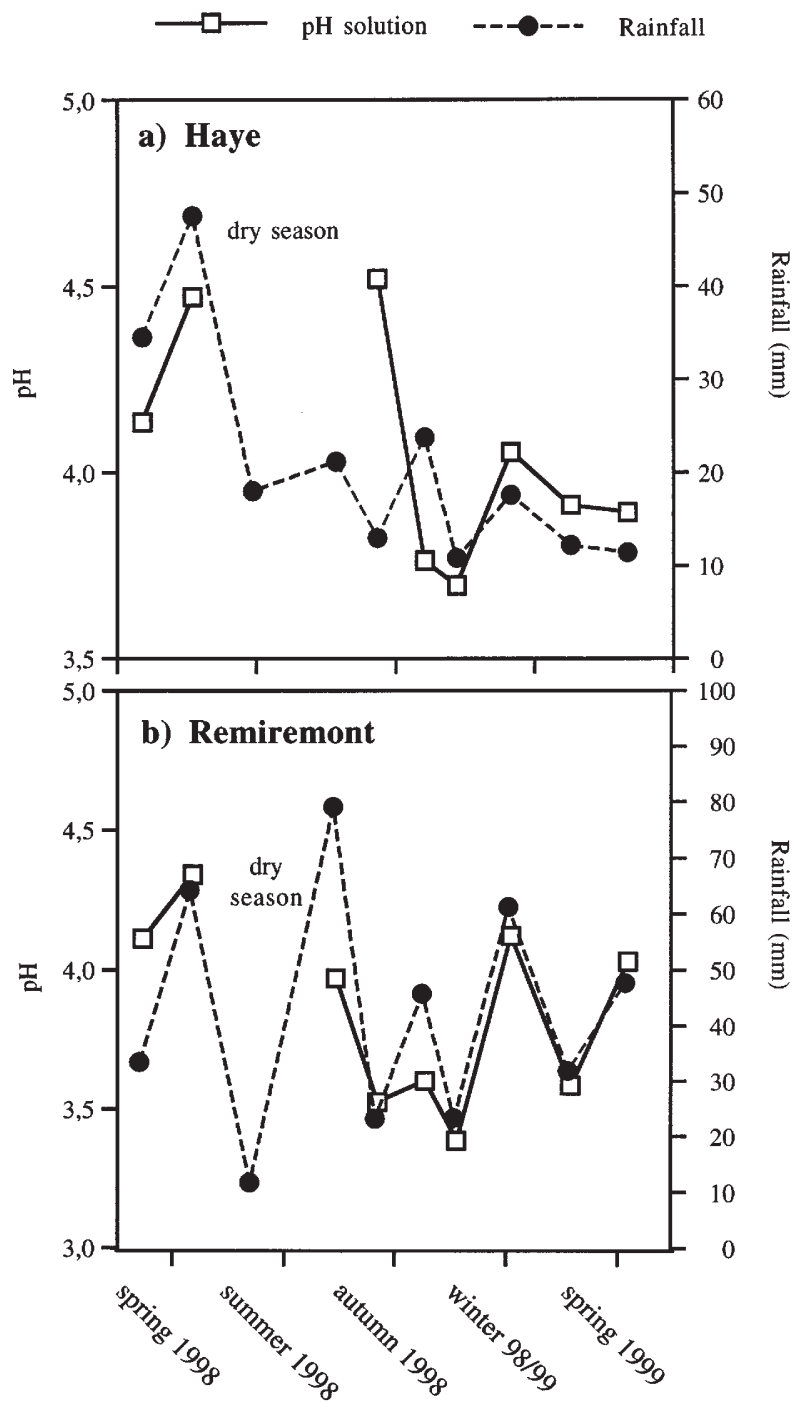

Figure 1. The relationship between soil solution $\mathrm{pH}$ and the amount of rainfalls during the eight days before sampling.

Soil solutions were more concentrated at Haye than at Remiremont (table IIIa). Mean solution concentrations at Haye were at least twice those at Remiremont (except for $\mathrm{NH}_{4}{ }^{+}-\mathrm{N}$ ). This difference was particularly large for $\mathrm{Ca}^{2+}, \mathrm{Mn}^{2+}$ and $\mathrm{NO}_{3}{ }^{-}-\mathrm{N}$. There was no significant difference between sites for solution $\mathrm{pH}$. The $\left[\mathrm{NO}_{3}{ }^{-}-\mathrm{N} /\right.$ $\left.\left(\mathrm{NO}_{3}{ }^{-}-\mathrm{N}+\mathrm{NH}_{4}{ }^{+}-\mathrm{N}\right)\right]$ ratio was significantly higher $(p<0.001)$ at Haye $(0.89 \pm 0.02)$ than at Remiremont $(0.35 \pm 0.03)$. 


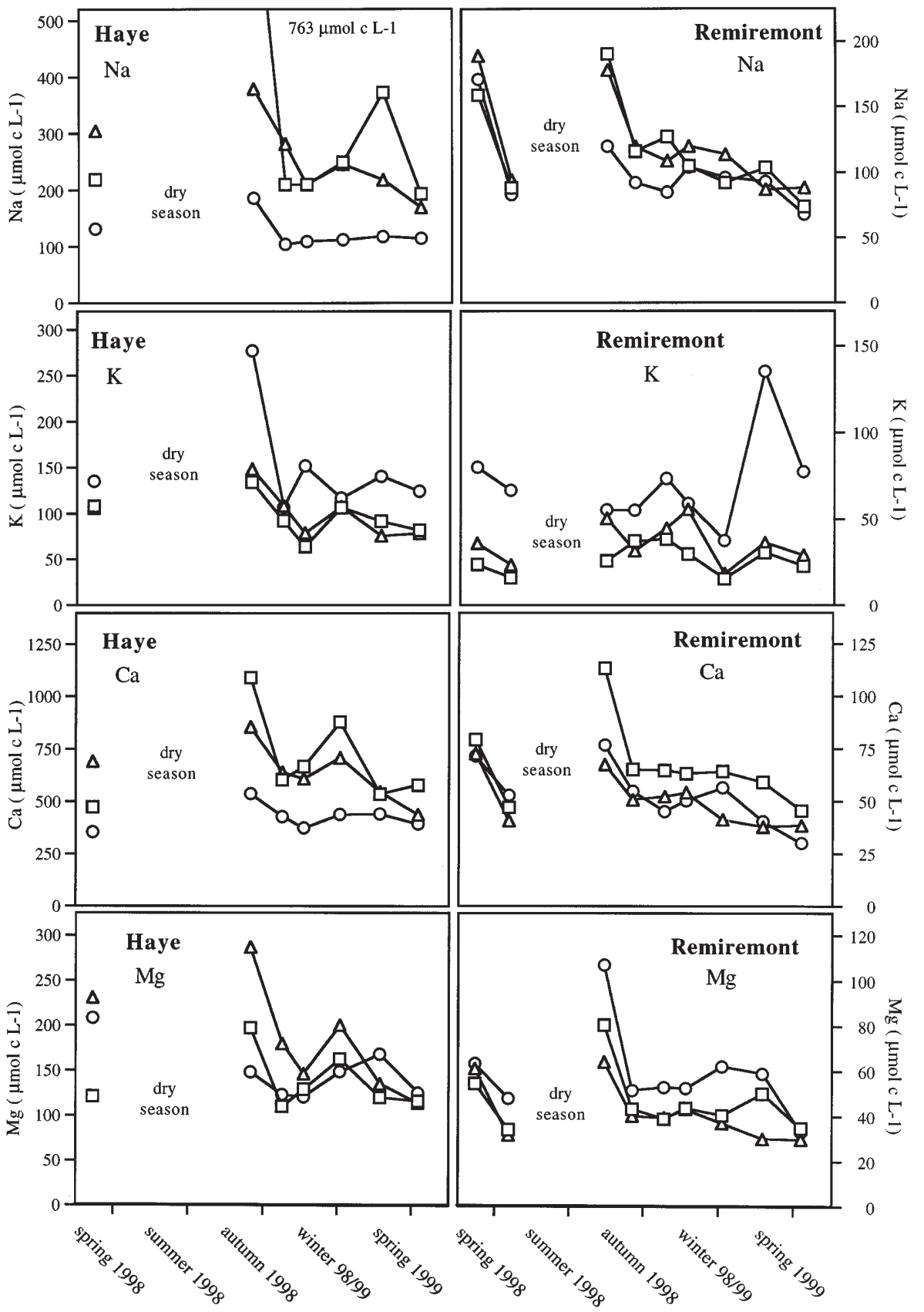

Figure 2. The effect of tree species on soil solution (continued on next page). 
$($ Douglas fir $=\square ;$ Norway spruce $=\Delta ;$ Hardwood $=0$ )

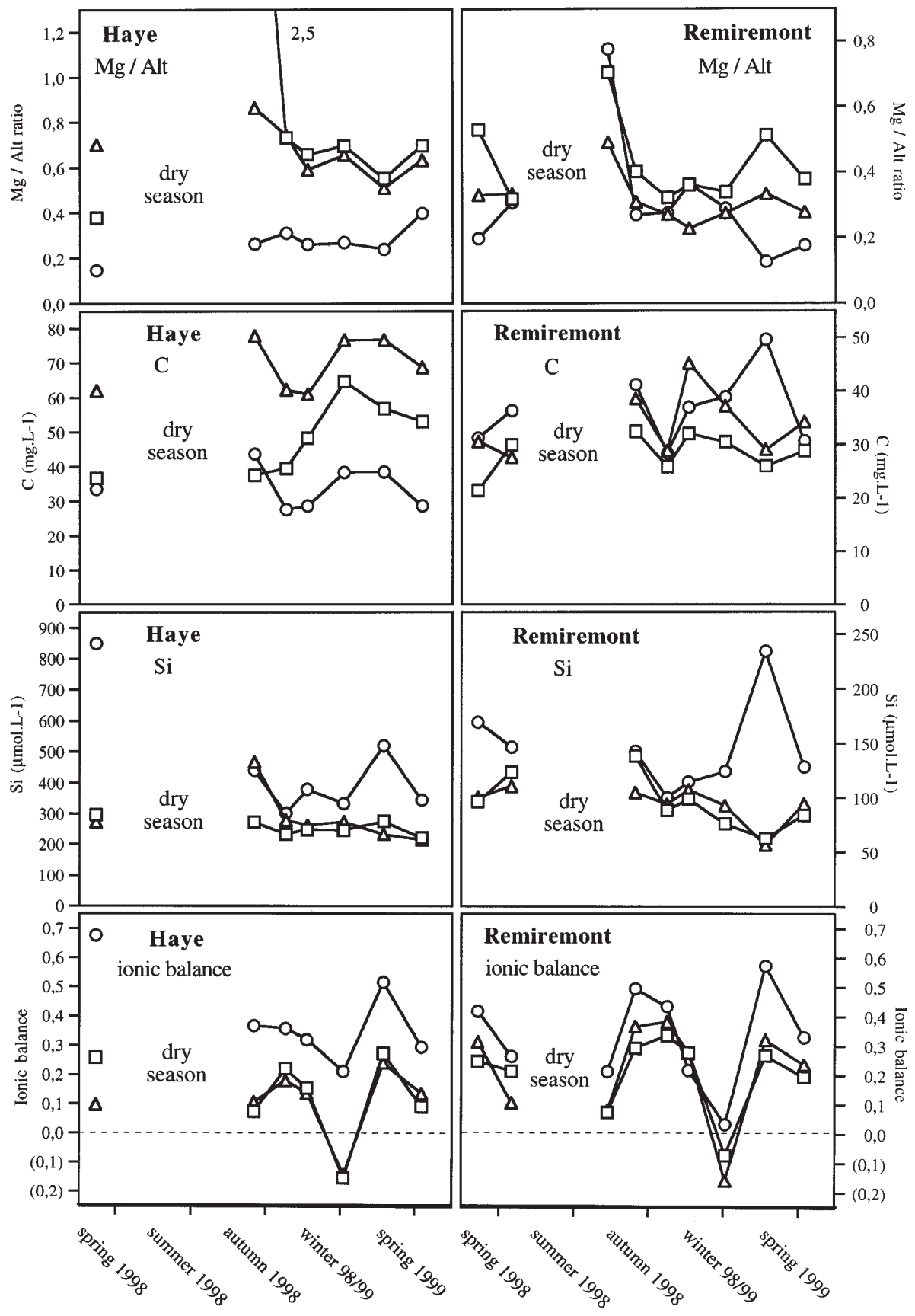

Figure 2. The effect of tree species on soil solution. 


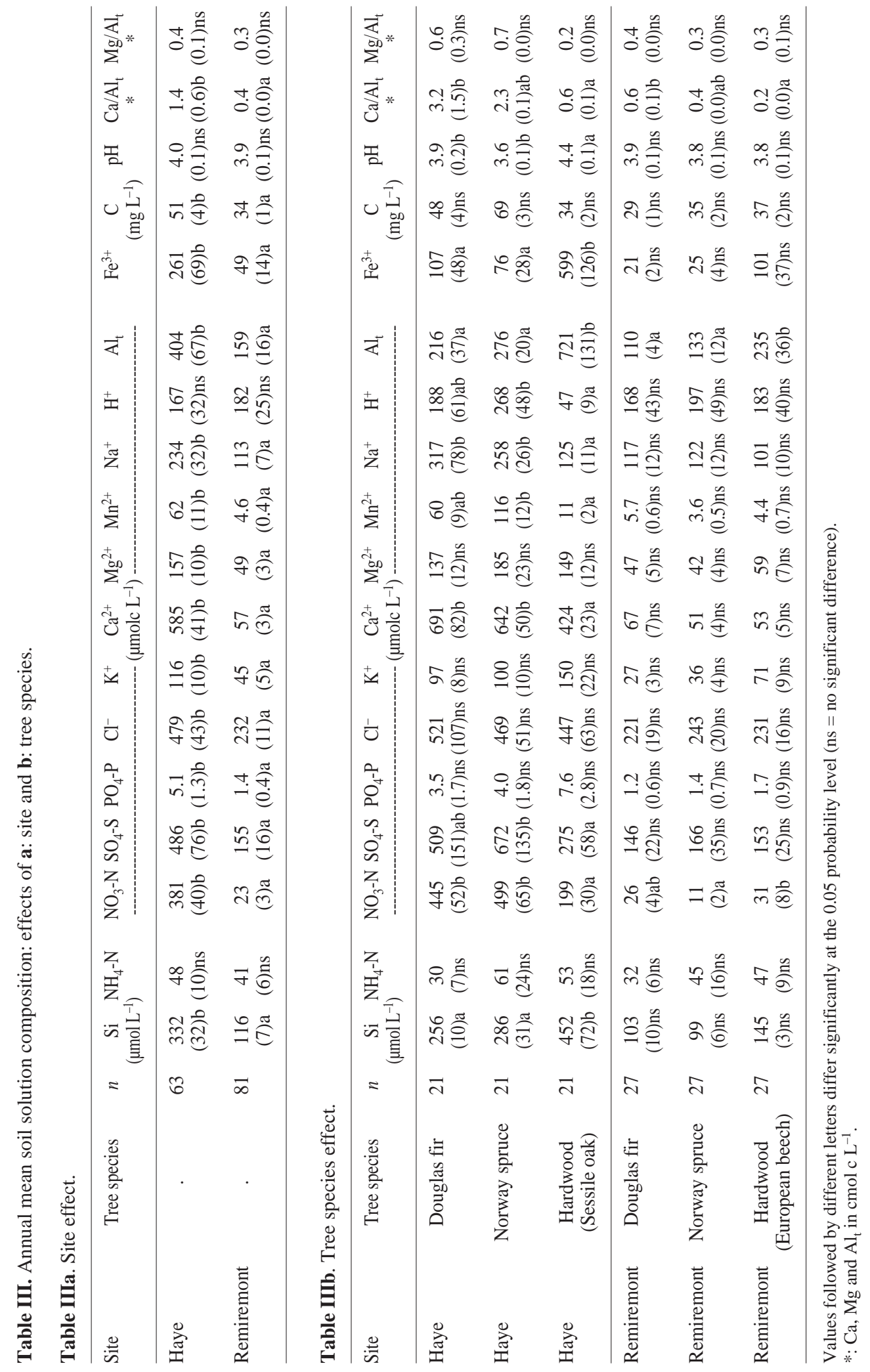




\subsection{Differences among tree species}

Haye:

During soil sample sieving, it was noted that there were quite numerous earthworms in Sessile oak soil whereas none were present in Douglas fir and Norway spruce soils. Some ant-hills were observed in the Norway spruce stand.

Soil moisture was significantly higher $(p<0.05)$ under Sessile oak $(35.1 \pm 1.0 \mathrm{~g}$ of water for $100 \mathrm{~g}$ of dry soil) and under Norway spruce $(36.0 \pm 2.2)$ than under Douglas fir $(29.7 \pm 1.3)$. The $\mathrm{pH}$ of soil solutions under hardwood stand was at least 0.5 unit higher than under coniferous stands (table IIIb). Solution concentrations of $\mathrm{SO}_{4}{ }^{-2}-\mathrm{S}$ and $\mathrm{Na}^{+}$were lower under hardwoods than under Norway spruce and Douglas fir (table IIIb). $\mathrm{NO}_{3}{ }^{-}-\mathrm{N}$ concentrations and $\left[\mathrm{NO}_{3}{ }^{-}-\mathrm{N} /\left(\mathrm{NO}_{3}{ }^{-} \mathrm{N}+\right.\right.$ $\left.\mathrm{NH}_{4}^{+}-\mathrm{N}\right)$ ] ratios were lower under hardwood stand than under coniferous stands. Such was also the case for $\mathrm{Ca}^{2+}$ concentrations and $\mathrm{Ca} / \mathrm{Al}_{\mathrm{t}}$ ratios. $\mathrm{Si}, \mathrm{Fe}^{3+}$ and $\mathrm{Al}_{\mathrm{t}}$ concentrations were higher under hardwood stand than under coniferous stands. $\mathrm{Mn}^{2+}$ concentrations of solutions were higher under Norway spruce than under hardwoods.

There was no statistically significant differences among tree species for the other variables. However, there were some tendencies for $\mathrm{K}^{+}$(figure $2 a$ ) as well as for $\mathrm{Mg} / \mathrm{Al}_{\mathrm{t}}, \mathrm{C}$ and ionic balance (figure $2 b$ ). It seems that $\mathrm{K}^{+}$concentrations were higher under hardwoods than under coniferous species. This was also the case with the ionic balance. In contrast, solutions under hardwoods had lower values of $\mathrm{C}$ concentration and of $\mathrm{Mg} / \mathrm{Al}_{\mathrm{t}}$ ratio than under coniferous species. Ranked according to $\mathrm{C}$ concentration, tree species were as follows: Norway spruce $>$ Douglas fir $>$ Sessile oak.

\section{Remiremont:}

Soil samples from the European beech stand contained a few more arthropoda than samples from coniferous stands. Soil moisture was significantly higher $(p<0.05)$ under European beech than under Norway spruce and Douglas fir (respectively: $66.9 \pm 3.6 \mathrm{~g}$ of water for $100 \mathrm{~g}$ of dry soil, $52.3 \pm 2.2$ and $49.6 \pm 1.9$ ). The tree species effect on the composition of soil solutions was not nearly so clearly expressed at Remiremont as at Haye (table IIIb). There were significant differences $(p<0.05)$ only for $\mathrm{NO}_{3}^{-}-\mathrm{N}, \mathrm{Al}_{\mathrm{t}}$ and $\mathrm{Ca} / \mathrm{Al}_{\mathrm{t}}$ ratio. Compared to coniferous species, hardwood had higher values for $\mathrm{NO}_{3}{ }^{-} \mathrm{N}$ and $\mathrm{Al}_{\mathrm{t}}$, and lower values for the $\mathrm{Ca} / \mathrm{Al}_{\mathrm{t}}$ ratio. Although results were not statistically significant for the other variables, it seems that there were some differences for $\mathrm{K}^{+}, \mathrm{Ca}^{2+}$ and $\mathrm{Mg}^{2+}$ (figure $2 a$ ) as well as for $\mathrm{Mg} / \mathrm{Al}_{\mathrm{t}}$ ratio, $\mathrm{Si}$ and ionic balance (figure $2 b$ ).
Hardwood had higher values than coniferous species for $\mathrm{K}^{+}, \mathrm{Mg}^{2+}, \mathrm{Si}$ and ionic balance. Douglas fir had the highest concentrations of $\mathrm{Ca}^{2+}$ and seems to have a higher $\mathrm{Mg} / \mathrm{Al}_{\mathrm{t}}$ ratio than Norway spruce.

\section{DISCUSSION}

The pH of capillary solutions extracted from topsoils was statistically linked to the amount of rainfall. The more the rainfall, the higher the soil solution $\mathrm{pH}$. The measurements made in the "national network for the long-term monitoring of forest ecosystems" (RENECOFOR) showed that rainfall $\mathrm{pH}$ in the area of the present study was between 5.0 to 5.5 [50]. This $\mathrm{pH}$ is higher than those of soils (table II). When the amount of rainfall was high, soil solutions were less acidic as they contain a lot of solution with quite high $\mathrm{pH}$ [20]. The effect of rainfall on soil solution $\mathrm{pH}$ was more clearly expressed at Remiremont than at Haye because the rainfall at Remiremont was more than twice that at Haye.

Only one year of monitoring was available. Therefore, it is difficult to show a seasonal trend in the results. However, it seemed that the summer dessication tended to concentrate the soil solutions.

Soil moisture at Remiremont was higher than at Haye because of the higher quantity of rainfall and of the more homogeneous soil particle size distribution (table II). Soil solutions at Haye were more concentrated than those of Remiremont. Although rainfall had low concentrations [50], the difference in concentrations can not be explained solely by the difference of rainfall amounts, especially $\mathrm{Ca}^{2+}, \mathrm{Fe}^{3+}, \mathrm{Mn}^{2+}$ and N. For these elements, it is probable that the Haye bedrock (silt on decarbonatation materials from limestone) produced more calcium and easily weathereable minerals than the Remiremont bedrock (silt on sandstone).

Soil moisture was higher under hardwoods than under coniferous species: hardwoods $\geq$ Norway spruce $\geq$ Douglas fir. Nihlgard [35] and Benecke and Mayer [4] have already shown that soils are drier under Norway spruce than under European beech. This behaviour was due to the higher ability of coniferous tree species to intercept rainfall $[3,24]$.

In contrast to Haye, Remiremont showed few differences in soil solution composition among tree species. However, other authors have established that tree species modify the composition of soil solutions (e.g. [1, 14]). The results from the Remiremont site can be explained by two phenomena: (i) the very high amount of rainfall at Remiremont diluted soil solutions and hid the tree species effect. (ii) as the soil was more desaturated than at Haye (saturation index for exchangeable earth-alkaline 
Table IV. The effect of tree species on aluminum speciation in soil solution.

\begin{tabular}{|c|c|c|c|c|c|c|c|c|c|c|c|c|c|}
\hline References & Localisation & $\begin{array}{c}\text { Soil } \\
\text { depth } \\
\text { (cm) }\end{array}$ & Tree species & $\mathrm{pH}$ & $\mathrm{Ca}$ & $\mathrm{mol} \mathrm{L}^{-}$ & $\begin{array}{l}\mathrm{Al} \\
\text { total } \\
\left(\mathrm{Al}_{\mathrm{t}}\right)\end{array}$ & $\begin{array}{c}\mathrm{Al} \\
\underset{\left(\mathrm{Al} \mathrm{l}_{\mathrm{i}}\right)}{\text { inorganic }}\end{array}$ & $\mathrm{Al}_{\mathrm{i}} / \mathrm{Al}_{\mathrm{t}}$ & $\mathrm{Ca} / \mathrm{Al}_{\mathrm{t}}$ & $\mathrm{Mg} / \mathrm{Al}_{\mathrm{t}}$ & $\mathrm{Ca} / \mathrm{Al}_{\mathrm{i}}$ & $\mathrm{Mg} / \mathrm{Al}_{\mathrm{i}}$ \\
\hline \multirow{4}{*}[22,23]{} & \multirow{4}{*}{$\begin{array}{l}\text { Sor catchment } \\
\quad \text { (Spain) }\end{array}$} & \multirow{4}{*}{ 0-10 } & Pinus sylvestris & 4.4 & 50 & 41 & 41 & 33 & 0.8 & 1.2 & 1.0 & 1.5 & 1.2 \\
\hline & & & Pinus sylvestris & 4.5 & 45 & 78 & 65 & 58 & 0.9 & 0.7 & 1.2 & 0.8 & 1.3 \\
\hline & & & Quercus robur & 4.4 & 60 & 70 & 75 & 37 & 0.5 & 0.8 & 0.9 & 1.6 & 1.9 \\
\hline & & & Quercus robur & 4.4 & 135 & 144 & 153 & 76 & 0.5 & 0.9 & 0.9 & 1.8 & 1.9 \\
\hline \multirow{2}{*}{ [17] } & \multirow{2}{*}{$\begin{array}{l}\text { Schneeberg } \\
\text { (Germany) }\end{array}$} & \multirow{2}{*}{$0-5$} & Picea abies & 3.3 & 98 & 25 & 62 & 41 & 0.7 & 1.6 & 0.4 & 2.4 & 0.6 \\
\hline & & & Fagus sylvatica & 3.6 & 125 & 33 & 70 & 24 & 0.3 & 1.8 & 0.5 & 5.2 & 1.4 \\
\hline \multirow{2}{*}{ [17] } & \multirow{2}{*}{$\begin{array}{l}\text { Silverbach } \\
\text { (Germany) }\end{array}$} & \multirow{2}{*}{$0-5$} & Picea abies & 3.4 & 267 & 66 & 163 & 96 & 0.6 & 1.6 & 0.4 & 2.8 & 0.7 \\
\hline & & & Fagus sylvatica & 3.7 & 181 & 45 & 128 & 90 & 0.7 & 1.4 & 0.4 & 2.0 & 0.5 \\
\hline
\end{tabular}

cations at $5 \mathrm{~cm}$ depth: Remiremont $=7 \%$; Haye $=46 \%$ ), the buffering capacity of Haye was more sensitive and thus influenced by the impact of tree species on the environment.

At Haye, soil solutions under Norway spruce and Douglas fir were more concentrated in $\mathrm{SO}_{4}{ }^{2-}$ and $\mathrm{Na}^{+}$ than those under hardwoods. It has been established that the origin of these elements in acidic soils was mainly atmospheric [26]. It suggested that Norway spruce and Douglas fir intercepted the atmospheric deposition more than Sessile oak do. Brown and Iles [14], Ranger and Nys [38] and Berkvist and Folkesson [5] have measured the extent to which coniferous species (Picea abies, Pinus sylvatica) intercept atmospheric deposition more than hardwood species do (Quercus petraea, Fagus sylvatica, Betula pendula). It is probable that the high soil solution concentrations of $\mathrm{NO}_{3}^{-}-\mathrm{N}$ and $\mathrm{Ca}^{2+}$ under coniferous species were partly due to high atmospheric deposition. Thus, on an acidic soil of northeastern France, Ranger and Nys [38] have reported that a Norway spruce stand intercepted $155 \%$ more $\mathrm{N}$ than a Sessile oak stand, $50 \%$ more S, $10 \%$ more Ca but $15 \%$ less K. It should be noted that the age of the hardwood stand at Remiremont could have masked this effect (table I). Indeed, Hugues et al. [27] have shown with several Picea sitchensis chronosequences that atmospheric deposition to canopies increases with stand age. Furthermore, the introduction of exotic tree species, such as Norway spruce and Douglas fir, could have led to mineralisation of old organic matter in soil and, then, to higher nitrification flux. This hypothesis was suggested by Jussy et al. [28], but still need a validation.
The $\mathrm{pH}$ of soil solutions at Haye were tree species dependent. There was at least 0.5 unit difference between the solutions of harwoods and those of coniferous tree species. The effect of tree species on solution $\mathrm{pH}$ was as follows: Sessile oak $>$ Douglas fir $\geq$ Norway spruce. This result is due to the higher ability of coniferous tree species to intercept atmospheric deposition, which is potentially acidic. Soil solutions were more acidified under coniferous species than under hardwoods also because of the low $\mathrm{pH}$ of coniferous species needles [36] and the more acidic organic matter of Norway spruce [46]. The acidity of the coniferous stands at Haye could prevent burrowing fauna, such as earthworms, from colonizing the soil [16]. Root exudates could have influenced the results as they are tree species dependent [45].

For both sites, soil solutions were more concentrated in $\mathrm{K}^{+}$under hardwoods than under coniferous species. This difference in behaviour for $\mathrm{K}^{+}$between hardwoods and coniferous species has been mentioned in a composition study on artificial soil [48]. The $\mathrm{K}$ contents of Sessile oak and European beech leaves are 50\% higher than those of Norway spruce and Douglas fir needles [6, 9]. Therefore, processes like litter mineralisation and foliage recretion could have promoted a higher concentration of this element under hardwood species than under coniferous species.

The high concentrations of $\mathrm{Mn}^{2+}$ in Norway spruce soil solutions compared to hardwood solutions were due to soil solution $\mathrm{pH}$. Indeed, this element is soluble in acidic solution [20]. 
At Haye, the tree species effect on the $\mathrm{C}$ content of soil solution was the inverse of its effect on $\mathrm{pH}$ : Norway spruce $\geq$ Douglas fir $\geq$ Sessile oak. Raulund-Rasmussen et al. [39] have also shown that the $C$ content of soil solution was: Norway spruce $>$ European beech $=$ Pedunculated oak. As previously stated, this could be the result of an enhanced mineralisation of old soil organic matter which increases the soil acidification under coniferous tree species. It should be underlined that $\mathrm{C}$ content of solutions is correlated to its ability to alter minerals [39]. Nevertheless, as concentrations of Si was also highest in Sessile oak soil solutions, it cannot be concluded that the weathering rate of soil minerals under Norway spruce was higher than under Sessile oak.

At Haye, as at Remiremont, soil solutions under hardwoods showed a larger ionic inbalance (positive balance) than under coniferous species. For the present study, Al was considered as $\mathrm{Al}^{3+}$ because solutions were acidic. Solutions $\mathrm{pH}$ could explain the results of Haye as Al speciation is $\mathrm{pH}$ dependent [41]. Indeed, Driscoll [18] has shown that, in solutions with organic matter, $\mathrm{Al}^{3+}$ represented $100 \%$ of $\mathrm{Al}_{\mathrm{t}}$ at $\mathrm{pH}=3.6(\mathrm{pH}$ of soil solutions under Norway spruce), $90 \%$ of $\mathrm{Al}_{\mathrm{t}}$ at $\mathrm{pH}=3.9$ (Douglas fir), but only $50 \%$ at $\mathrm{pH}=4.4$ (Sessile oak). Moreover, for soil solutions at $\mathrm{pH}=4.4$, Fernandez-Sanjurjo et al. [23] have shown that only $20 \%$ of $\mathrm{Al}_{t}$ was in the $\mathrm{Al}^{3+}$ chemical form. Therefore some Al in hardwood soil solutions may not be trivalent. This has led to an overestimation of the total positive charge of solutions under hardwoods. Nevertheless, soil solutions under the hardwood stand at Remiremont were also unbalanced, though no less acidic than those under the coniferous stands. This situation suggested that hardwood stands did have not the same Al speciation as coniferous stands. Thus, according to literature data (table $I V$ ), it seems that the (inorganic $\mathrm{Al}$ i.e. almost $\left.\mathrm{Al}^{3+}\right) /\left(\mathrm{Al}_{\mathrm{t}}\right)$ ratio is often lower under hardwood stands than under coniferous stands (except at Silverbach, [17]). If such was the case at Remiremont, it would explain the imbalance of the European beech solutions. It is possible that the phenomena which have led to modification of the Al speciation under the hardwood stands have also enhanced the solubilization of $\mathrm{Al}_{\mathrm{t}}, \mathrm{Fe}$ and $\mathrm{Si}$ (table IIIb). These processes are probably dependent on biological cycles, as $\mathrm{Si}$ and $\mathrm{Al}$ fluxes in forest ecosystems are partly controlled by tree litter [31]. For the present study, $\mathrm{Ca} / \mathrm{Al}_{\mathrm{t}}$ and $\mathrm{Mg} / \mathrm{Al}_{\mathrm{t}}$ ratios of hardwood solutions were lower than those of coniferous species solutions. Such was also the case of Skeffington [44]. But Brown and Iles [14] and Koch and Matzner [29] have shown the opposite results. $\mathrm{Ca} / \mathrm{Al}_{\mathrm{t}}$ and $\mathrm{Mg} / \mathrm{Al}_{\mathrm{t}}$ ratios are often used as indicator values of the potential toxicity of $\mathrm{Al}$ for vegetation on very desaturated soils [33]. However, only few forms of $\mathrm{Al}$ are toxic (mainly $\mathrm{Al}^{3+}$ ). Therefore, $\mathrm{Ca} / \mathrm{Al}_{\mathrm{t}}$ and $\mathrm{Mg} / \mathrm{Al}_{\mathrm{t}}$ ratios are not efficient indicators of potential Al toxicity [10] because they do not take into account the Al speciation [11]. It should be observed that the tree species gradient for $\mathrm{Ca} / \mathrm{Al}$ and $\mathrm{Mg} / \mathrm{Al}$ ratios is reversed when only inorganic $\mathrm{Al}$ (i.e. almost $\mathrm{Al}^{3+}$ ) is considered, instead of total $\mathrm{Al}$ (table IV). Thus, $\mathrm{Al}_{\mathrm{t}}$ is not a efficient index of $\mathrm{Al}$ toxicity and, therefore, it is difficult to discuss the ecological meaning of the ratios of the present study.

\section{CONCLUSION}

The $\mathrm{pH}$ and the composition of capillary solutions of topsoils were highly dependent on the amount of rainfall. The bedrock characteristics were also an important factor controlling the chemistry of capillary solutions.

The tree species effect on topsoil solutions was small when the amount of rainfall was high. Exotic coniferous tree species intercepted rainfall and atmospheric deposition more readly than did native hardwoods. This situation led to a decrease in soil water content and to an acidification under coniferous stands. It is also probable that the introduction of coniferous tree species has modified the biogeochemical cycles of some elements, such as $\mathrm{K}, \mathrm{N}$ or $\mathrm{Al}$, in the ecosystems, suggesting different nutrition modes according to tree species. Complementary works are required to determine the tree species effect on the long term fertility of acidic soils. These works should concern the study of gravitational solutions so as to measure the impact of tree species on the amounts of elements lost by drainage.

Acknowledgements: We would like to thank: $\mathrm{Mr}$ Allié, Melle Depaquis, Mme Clausse, Mr Didier, Mr Gérard and Mr Zeller for technical assistance on field; Mr Allié, Mr Belkacem, Mme Bienaimé, Mr Bonnaud, Mme Gelhaye, Mr Goeltl and Mr Pollier for technical assistance in laboratory; the École Nationale du Genie Rural et des Eaux et Forêts and the Office National des Forêts for providing all facilities during experimentation; Mr White and the INRA linguistic service at Jouy-enJosas for revising the English of this work.

\section{REFERENCES}

[1] Adamson J.K., Hornung M., Kennedy V.H., Norris D.A., Paterson I.S., Stevens P.A., Soil solution chemistry and throughfall under adjacent stands of Japanase Larch and Sitka Spruce at three contrasting locations in Britain, Forestry 66 (1993) 51-68.

[2] Anne P., Sur le dosage rapide du carbone organique des sols, Ann. Agron. 2 (1945) 161-172. 
[3] Aussenac G., Couverts forestiers et facteurs du climat : Leurs interactions, conséquences écophysiologiques chez quelques résineux, Thèse Univ. Nancy I, 1975, 234 p.

[4] Benecke P., Mayer R., Aspects of soil water behavior as related to beech and spruce stands. Some results of the water balance investigations, in: Ellenberg H. (Ed.), Integrated experimental ecology - Methods and results of ecosystem research in the german Solling project, Ecological Vol. 2, SpringerVerlag, Berlin, 1971, pp. 153-163.

[5] Bergkvist B., Folkeson L., The influence of tree species on acid deposition, proton budgets and element fluxes in south Swedish forest ecosystems, Ecol. Bull. 44 (1995) 90-99.

[6] Bergmann W., Ernährungsstörungen bei Kulturpflanzen. Entstehung, visuelle und analytishe diagnose, Bergmann W. (Ed.), 2nd edn., Gustav Fisher Verlag, Stuttgard, 1988.

[7] Binkley D., The influence of tree species on forest soils: Processes and Patterns, in: Mead D.J., Cornforth I.S. (Eds.), Proceedings of the trees and soil workshop, 1994, Agronomy Society of New Zealand Special Publication \#10., Lincoln Univ. Press, Canterbury (N.Z.), 1995, pp. 1-33.

[8] Boettcher S.E., Single-tree influence on soil properties in the mountains of eastern Kentucky, Ecology 71 (1990) $1365-1372$

[9] Bonneau M., Le diagnostic foliaire, Rev. For. Fr. XL (1988) 19-26.

[10] Boudot J.P., Becquer T., Merlet D., Rouiller J., Ranger J., Dambrine E., Mohamed D.A., Potential role of aluminium toxicity in nutrient deficiencis as related to forest decline: An assessment of soil solution data from the Vosges mountains, in: Landmann G., Bonneau M. (Eds.), Forest decline and atmospheric deposition effects in the french mountains, SpringerVerlag, Berlin, 1994, pp. 270-285.

[11] Boudot J.P., Becquer T., Merlet D., Rouiller J., Aluminium toxicity in declining forests: a general overview with a seasonal assessment in a silver fir forest in the Vosges mountains (France), Ann. Sci. For. 51 (1994) 27-51.

[12] Bremmer J.M., Determination of nitrogen in soil by the Kjeldahl method, J. Agric. Sci. 55 (1960) 11-33.

[13] Bringmark E., Spatial variation in soil $\mathrm{pH}$ of beech forests in relation to buffering properties and soil depths, Oikos 54 (1989) 165-177.

[14] Brown A.H.F., Iles M.A., Water chemistry profiles under four tree species at Gisburn, NW England, Forestry 64 (1991) 169-187.

[15] Carleton T.J., Kavanagh T., Influence of stand age and spatial location on throughfall chemistry beneath black spruce, Can. J. For. Res. 20 (1990) 1917-1925.

[16] Càrcamo H.A., Parkinson D., Bargshoon D., Distribution of earthworms along a sharp acidification gradient, Pedobiologia 42 (1998) 88-95.

[17] Davis M.R., Chemical composition of soil solutions extracted from New Zealand beech forests and West German beech and spruce forests, Plant Soil 126 (1990) 237-246.

[18] Driscoll C.T., The chemistry of aluminum in surface waters, in: Sposiro G. (Ed.), The environmental chemistry of aluminum, CRC press, Boca Raton, FL, 1989, pp. 241-277.
[19] Duchaufour P., Bonneau M., Une nouvelle méthode de dosage du phosphore assimilable dans les sols forestiers, Bull. Assoc. Fr. Etude. Sol. 4 (1959) 193-198.

[20] Duchaufour P., Pédologie : 1. Pédogénèse et classification, Masson, Paris, 1977.

[21] Falkengren-Grerup U., Effect of stemflow on beech forest soils and vegetation in southern sweden, J. Appl. Ecol. 26 (1989) 341-352.

[22] Fernandez-Sanjurjo M.J., Alvarez E., Fernandez Vega V., Garcia-Rodeja E., Chemistry of soil solutions under different kinds of vegetation in the vicinity of a thermal power station, Environ. Pollut. 101 (1998) 131-142.

[23] Fernandez-Sanjurjo M.J., Alvarez E., Garcia-Rodeja E., Speciation and solubility control of aluminium in soils developed from slates of the river Sor watershed (Galicia, NW Spain), Water Air Soil Pollut. 103 (1998) 35-53.

[24] Forgeard F., Gloaguen J.C., Touffet J., Interception des précipitations et apports au sol d'éléments minéraux par les eaux de pluie et les pluviolessivats dans une hêtraie atlantique et dans quelques peuplements résineux de Bretagne, Ann. Sci. For. 37 (1980) 53-71.

[25] Giesler R., Chemistry of soil solution extracted by centrifugation - Methodology and field applications, Ph.D. Thesis Univ. Umeå, Sweden, 1996.

[26] Hornung M., Reynolds B., Stevens P.A., Hugues S., Water quality changes from input to stream, in: Edwards R.W. (Ed.), Acid waters in Wales, Kluwer Academic Plublishers, Dordrecht, 1990, pp. 223-240.

[27] Hugues S., Norris D.A., Stevens P.A., Reynolds B., Williams T.G., Effects of forest age on surface drainage water and soil solution aluminium chemistry in stagnopodzols in Wales, Water Air Soil Pollut. 77 (1994) 115-139.

[28] Jussy J.H., Colin-Belgrand M., Ranger J., Production and root uptake of mineral nitrogen in a chronosequence of Douglas-fir (Pseudotsuga menziesii) in the Beaujolais Mounts, For. Ecol. Manage. 128 (2000) 197-209.

[29] Koch A.S., Matzner E., Heterogeneity of soil and soil solution chemistry under Norway spruce (Picea abies Karst.) and European beech (Fagus silvatica L.) as influenced by distance from the stem basis, Plant Soil 151 (1993) 227-237.

[30] Lundstrom U.S., Nyberg L., Danielsson L., van Hees P.A.W., Anderson M., Forest soil acidification: monitoring on the regional scale, Varmland, Sweden, Ambio 27 (1998) 551-556.

[31] Markewitz D., Richter D., The bio in aluminum and silicon geochemistry, Biochem. 42 (1998) 235-252.

[32] Marschner H., Root-induced changes in the availability of micronutrients in the rhizosphere. in: Waisel Y., Eshel A., Kafkafi U. (Eds.), Plants roots, the hidden half, Dekker inc., 1991, pp. 508-527.

[33] Matzner E., Blanck K., Hartmann G., Stock R., Needle chlorosis pattern in relation to soil chemical properties in two Norway spruce (Picea abies, Karts.) forests of the german Harz mountains, in: Bucher J.B., Bucher-Wallin I. (Eds.), Air pollution and forest decline, 1989, pp. 195-199. 
[34] Ministère de l'Agriculture de la Pêche et de l'Alimentation, La forêt et les industries du bois, Collection GraphAgri-Forêt-Bois, Édition bilingue Français-Anglais, Ministère de l'Agriculture, 1996.

[35] Nihlgard B., The microclimate in a beech and a spruce forest - a comparative study from Kongalund, Scania, Sweden, Bot. Notiser 122 (1969) 333-352.

[36] Nykvist N., Leaching and decomposition of water-soluble organic substances from different types of leaf and needle litter, Studia Forestalia Suecica 3 (1963) 1-31.

[37] Ranger J., Discours D., Mohamed-Ahamed D., Moares C., Dambrine E., Merlet D., Rouiller J., Comparaison des eaux liées et des eaux libres des sols de 3 peuplements d'épicéa commun (Picea abies Karst) des Vosges. Application à l'étude du fonctionnement actuel des sols et conséquences pour l'état sanitaire des peuplements, Ann. Sci. For. 50 (1993) 425-444.

[38] Ranger J., Nys C., The effect of spruce (Picea abies Karst.) on soil development: an analytic and experimental approach, Eur. J. Soil Sci. 45 (1994) 193-204.

[39] Raulund-Rasmussen K., Borggaard O.K., Hansen H.C.B., Olsson M., Effect of natural organic soil solutes on weathering rates of soil minerals, Eur. J. Soil Sci. 49 (1998) 397-406.

[40] Riha S.J., Senesac G., Pallant E., Effects of forest vegetation on spatial variability of surface mineral soil $\mathrm{pH}$, soluble aluminum and carbon, Water Air Soil Pollut. 31 (1986) 929-940.

[41] Ritchie G.S.P., Soluble alumium in acidic soils: principles and practicalities, Plant Soil 171 (1995) 17-27.

[42] Rouiller J., Guillet B., Bruckert S., Cations acides échangeables et acidités de surface. Approche analytique et incidence pédogénétique, Bull. Assoc. Fr. Étude Sol 2 (1980) 161-175.

[43] SAS institute Inc., SAS/STAT user's guide, Version 6, 3rd edition, North Carolina, USA: SAS institute, 1990.

[44] Skeffington R.A., Soil properties under three species of tree in southern England in relation to acid deposition in throughfall, in: Ulrich B., Pankrath J. (Eds.), Effect of accumulation of air pollutants in forest ecosystems, Reidel publishing Company, 1983, pp. 219-231.

[45] Smith W.H., Character and significance of forest tree root exudates, Ecology 57 (1976) 324-331.

[46] Strobel B.W, Bernhoft I., Borgaard O.K., Low-molecular-weight aliphatic carboxylic acids in soil solutions under different vegetations determined by capillary zone electrophoresis, Plant Soil 212 (1999) 115-121.

[47] Tamm O., Um best äming ow de oorganiska komponenterna i markens gelcomplex, Meded Stat. Skogsfors. 19 (1922) 385-404.

[48] Tice K.R., Graham R.C., Wood H.B., Transformations of 2:1 phyllosilicates in 41-year-old soils under oak and pine, Geoderma 70 (1996) 49-62.

[49] Titus B.D., Mahendrappa M.K., Lysimeter system designs used in soils research: a review, Information report NX-301, Natural Resources of Canada, Canadian Forest Service, 1996.

[50] Ulrich E., Lanier M., Combes D., Dépôts atmosphériques, concentrations dans les brouillards et dans les solutions du sol (sous-réseau CATAENAT), Rapport scientifique sur les années 1993 à 1996, Office National des Forêts, 1998.

[51] Zabowski D., Ugolini F.C., Lysimeter and centrifuge soil solutions: seasonal differences between methods, Soil Sci. Soc. Am. J. 54 (1990) 1130-1135.

To access this journal online: www.edpsciences.org 